УДК 619:611.718:598.2

(C) 2012

Мельник О. П., доктор ветеринарних наук, професор, Друзь Н. В., аспірант*

Національний університет біоресурсів і природокористування України

\title{
АНАЛІЗ БІОМОРФОЛОГІЧНИХ ОСОБЛИВОСТЕЙ ТАЗОСТЕГНОВОГО СУГЛОБА ДЕЯКИХ ЛЕЛЕКОПОДІБНИХ
}

\section{Рецензент - доктор ветеринарних наук В. К. Костюк}

\begin{abstract}
Викладено аналіз біоморфологічних особливостей м'язів тазостегнового суглоба представника ряду лелекоподібних (руда чапля, чорний лелека, бугай великий). Встановлено, щзо у представників даного ряду ступінь диферениіації м'язів тазостегнового суглоба обумовлений крокуючим типом біпедальної локомоиії, а також біоморфологічними особливостями статики, щуо, у свою чергу, накладає певні відбитки на ступінь розвитку кожного окремого м'яза тазостегнового суглоба даного виду птахів. Окрім того встановлено ступінь розвитку м'язів тазостегнового суглоба та його м'язових груп.

Визначено, шуо маса м'язів розгиначів тазостегнового суглоба більша, ніж згиначів. Це дає змогу стверджувати, щзо співвідношення розгиначів тазостегнового суглоба у даного виду птахів до згиначів залежсть від утримання тазостегнового суглоба в гравітаційному полі Землі у певному положенні під час статики та локомочії.
\end{abstract}

Ключові слова: біоморфологія, руда чапля, чорний лелека, бугай великий, тазостегновий суглоб.

Постановка проблеми. Понад сто років тому К. Е. Ліндеман [1] у підручнику «Порівняльна анатомія м'язової системи хребетних тварин» писав, що «Порівняльна анатомія м'язової системи вивчена в теперішній час дуже недосконало.

Аналіз останніх досліджень i публікацій, у яких започатковано розв'язання проблеми. Окремі м'язи деяких тварин, особливо птахів, відомі, правда, дуже добре, досліджені до останніх дрібниць, але вся увага приділялася крилу $[2,3]$. Однак ці знання не підведені під певні загальні керівні схеми. У зв'язку з таким станом наших знань, доводиться бути або дуже коротким в описанні цісї системи органів, або поринути в ці дрібниці, які мають поки що тільки практичне значення» $[3,5,7]$. Те ж саме, на нашу думку, можна сказати і про м'язово-скелетну систему тазової кінцівки птахів. Хотілося б думати, що за багато десятиліть становище змінилося корінним чином на краще. Однак, як засвідчує аналіз біоморфологічних праць за останні десятиліття і висло- влювання з цього питання видатних морфологів, суттєвих змін на краще не відбулося $[4,6]$.

Мета і завдання дослідження. Метою дослідження було вивчити механізми функціонування різних м'язових елементів; встановити основні причини їх утворення; провести ревізію даних $\mathrm{i}$ основних концептуальних положень стосовно питань їх можливої диференціації, галуження, перистості залежно від утримання тазостегнового суглоба в гравітаційному полі Землі.

Матеріали та методи досліджень. Работа виконана на кафедрі анатомії тварин ім. акад. В. Г. Касьяненка Національного університету біоресурсів і природокористування України (м. Київ). Дослідження проводилися на трьох видах птахів ряду лелекоподібних, родини чаплевих - руда чапля Ardea purpurea і бугай великий - Botaurus steltaris та родини лелекових - чорний лелека Ciconia nigra. Міологічні дослідження тазостегнового суглоба проводили на фіксованих 10 \%-м розчином формаліну трупах. Після виявлення точок фіксації, м'язи розтинали 3 метою визначення наявності чи відсутності перистості. Крім того, 3 метою з'ясування ступеню розвитку м'язів і м'язових груп, кожен м'яз зважували.

Результати досліджень. М'язи тазостегнового суглоба (рис. 1-7) можна розділити на дві групи: згиначі (краніальний клубово-вертлужний та каудальний клубово-вертлужний) та розгиначі (медіальний затульний, сідничостегновий, внутрішній клубово-стегновий, зовнішній клубово-стегновий, каудальний тазовостегновий та глибокий сідничо-стегновий м'язи).

У представників досліджених видів лелеко подібних серед м'язів тазостегнового суглоба спостерігаються певні відмінності. Так, у рудої чаплі краніальний клубово-вертлужний м'яз починається м'язово, дорсальніше поперечної осі тазової кістки; у бугая великого починається м'язовими волокнами у ділянці краніальної половини преацетабулярного відділу тазової кістки.

* Науковий керівник - доктор ветеринарних наук, професор О. П. Мельник 
У чорного лелеки цей м'яз починається м'язовоапоневротично від краніальної частини тазової кістки. Закінчується м'яз у рудої чаплі м'язовими волокнами у ділянці краніальної половини преацетабулярного відділу тазової кістки. У бугая великого м'яз щільно прилягає до спинного гребеня й закінчується дорсально на поперечній осі клубової кістки. Щодо чорного лелеки, то краніальний клубово-вертлужний м'яз частково розгалужений на 2 пласти - поверхневий і глибокий. Поверхнева частина дещо менша і закінчується м'язово-апоневротично в ділянці тазостегнового суглоба, частково покриваючи його, а глибока - апоневротично в ділянці проксимальної частини великогомілкової кістки.

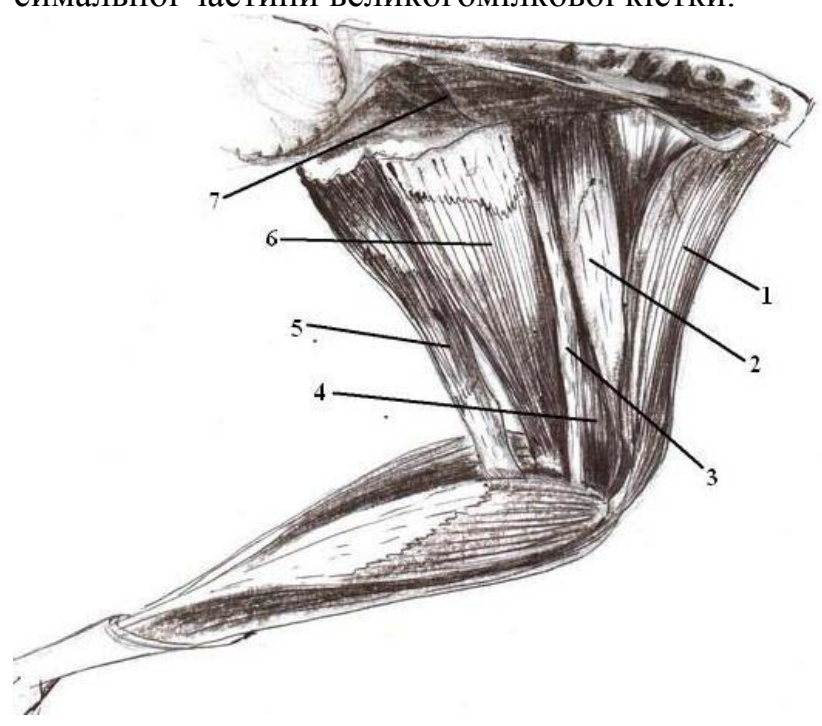

Рис. 1. М'язи тазостегнового суглоба рудої чаплі (медіальна поверхня):

1 - крінальний поздовжньовеликогомілковий; 2 -середній стегнововеликогомілковий; 3 -стегнова кістка;

4 - внутрішній стегново-великогомілковий;

5 -медіальний згинач гомілки;

6 - лобково-сідничо-стегновий;

7 -медіальний затульний м'яз.

Слід зазначити, що краніальний клубововертлужний м'яз у рудої чаплі має одноперисту структуру, а в бугая великого та чорного лелеки він повздовжньоволокнистий. Це, у свою чергу, свідчить, що даний м'яз у рудої чаплі знаходиться під дією більших функціональних навантажень, ніж у чорного лелеки та бугая великого.

Каудальний клубово-вертлужний м'яз у наших дослідженнях виявлений у рудої чаплі та бугая великого. Цей м'яз у рудої чаплі починається м’язово-апоневротично від дорсолатеральної частини клубової кістки, а у бугая великого - це один із найпотужніших м'язів, що також починається на дорсо-латеральній поверхні клубової кістки, але м'язово. Як у рудої чаплі, так і у бугая великого м'яз закінчується на латеральній поверхні вертела стегнової кістки м'язово. В обох випадках м'яз має поздовжньоволокнисту структуру.

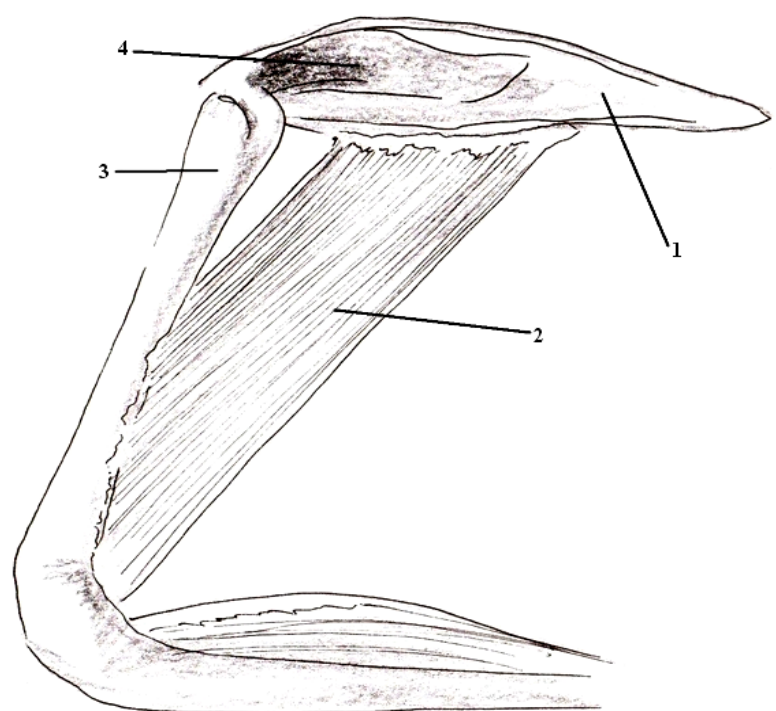

Рис. 2. М'язи тазостегнового суглоба рудої чаплі (медіальна поверхня):

1 - тазовий пояс; 2 - глибокий сідничокстегновий м'яз; 3 - стегнова кістка; 4 -медіальний затульний м'яз.

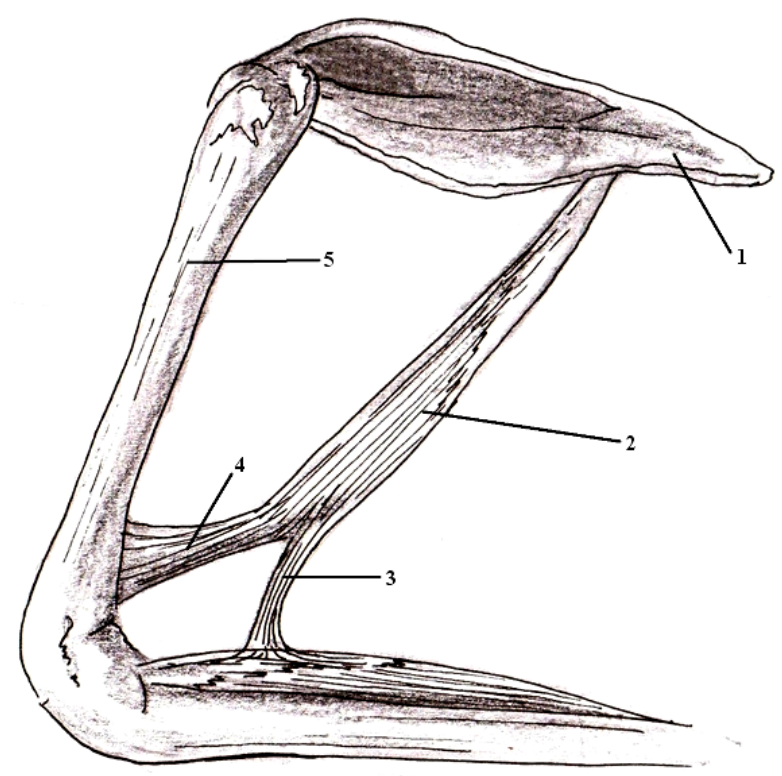

Рис. 3. М'язи тазостегнового суглоба рудої чаплі (латеральна поверхня):

1 -лобкова кістка; 2 -лобково-сідничостегновий м'яз; 3 - латеральна частина; 4 -медіальна частина; 5 - стегнова кістка. 


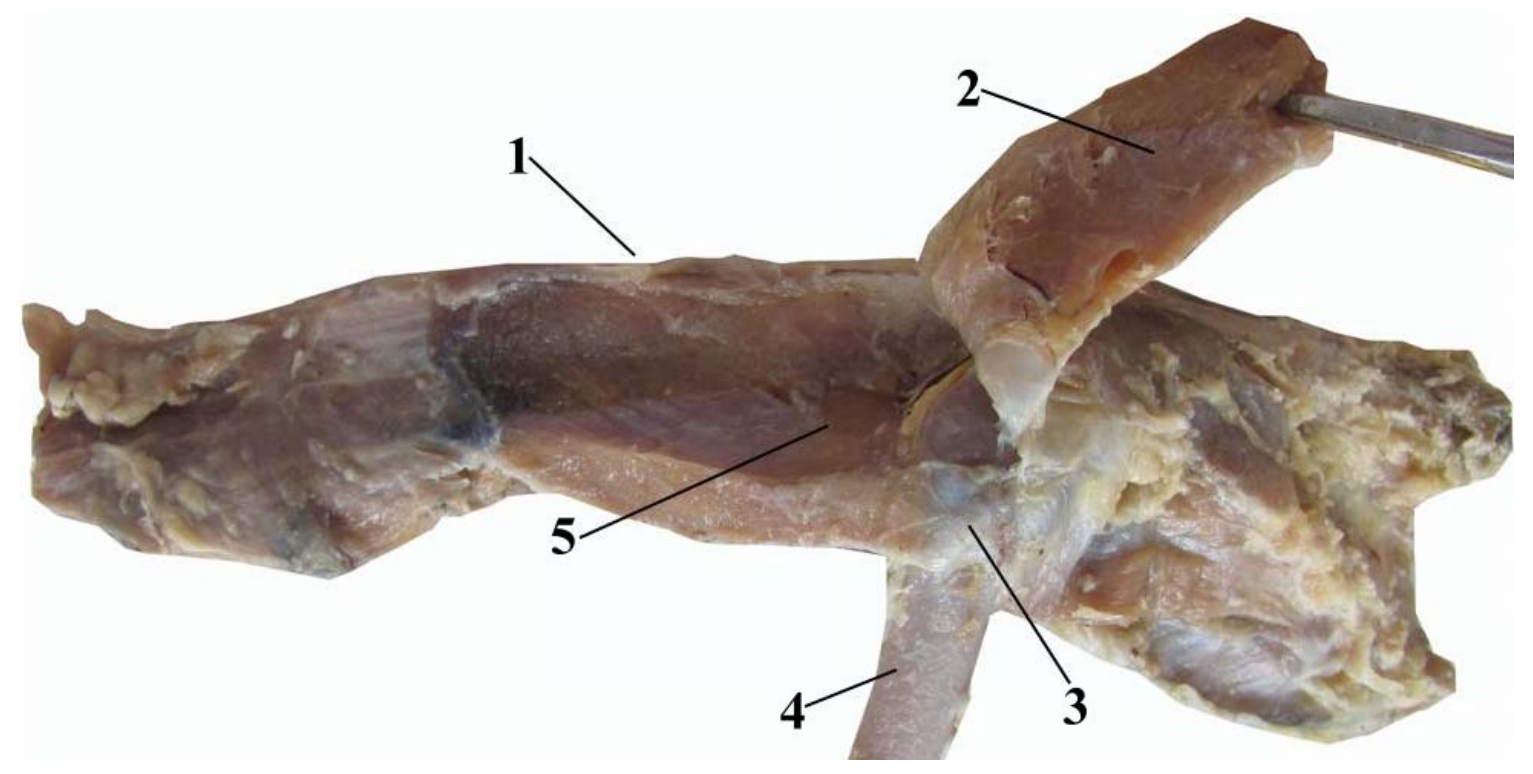

Рис. 4. М'язи тазостегнового суглоба бугая великого (латеральна поверхня):

1 - тазова кістка; 2 - каудальний клубово-вертлужний м'яз; 3 - тазостегновий суглоб; 4 - стегнова кістка; 5 - краніальний клубово-вертлужний м'яз.

Серед м'язів-розгиначів тазостегнового суглоба медіальний затульний м'яз в усіх видів починається м'язовими волокнами від вентрального краю лобкової та сідничої кістки. В ділянці затульного отвору м'яз, каудальний край якого частково сформований сухожильною мембраною у рудої чаплі й повністю - у чорного лелеки та бугая великого. Ця мембрана розміщена між лобковою та сідничою кістками. М'яз у всіх досліджених видів повністю виходить через затульний отвір, щільно прилягаючи до мембрани 3 медіальної сторони. Однак у чорного лелеки він поділяється на дві ніжки - апоневротичну та м'язову. Апоневротична закінчується на каудолатеральній поверхні проксимального кінця великого вертела, а м'язова фіксується там же, хоча дещо дистальніше. М'яз має одноперисту структуру. У рудої чаплі та великого бугая м'яз закінчується вище осі обертання тазостегнового суглоба. Слід зауважити, що медіальний затульний м'яз у рудої чаплі повздовжньо-волокнистий, а у чорного лелеки та бугая великого одноперестий, що свідчить про виконання цим м'язом у чорного лелеки та бугая великого більших функціональних навантажень.

Сідничо-стегновий м'яз в усіх досліджених видів починається м'язово-апоневротично від краніальної частини преацетабулярного відділу сідничої кістки й закінчується м'язово на дистальній поверхні стегнової кістки. М'яз у чорного лелеки та рудої чаплі одноперистий, а у бугая великого - поздовжньоволокнистий. У бугая великого наступних м'язів у наших дослідженнях виявлено не було.

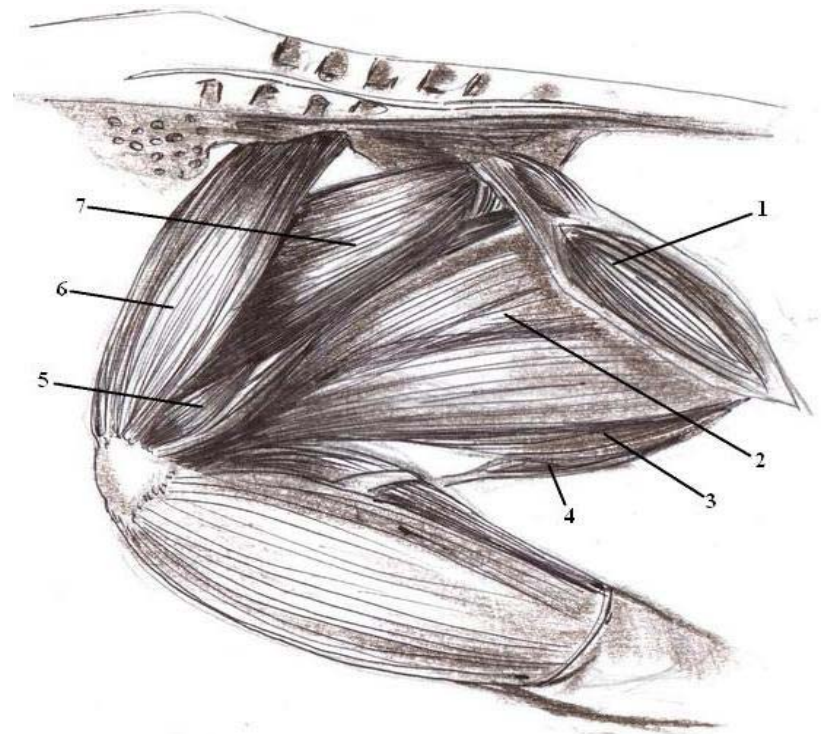

Рис. 5. М'язи тазової кінцівки чорного лелеки (медіальна поверхня):

1 -медіальний затульний м'яз;

2 - лобково-сідничо-стегновий м'яз;

3 - медіальний згинач гомілки;

4 - латеральний згинач гомілки;

5 - внутрішній стегново-великогомілковий;

6 - середній стегново-великогомілковий; 7 - зовнішній клубово-стегновий.

Внутрішній клубово-стегновий м'яз, який ізпоміж досліджених видів нами виявлено тільки у чорного лелеки, починається дещо каудальніше від краніального клубово-вертлужного м'яза, фіксується безпосередньо до стегнової кістки. Закінчується у каудо-медіальній частині тазової 
кістки перед преацетабулярним відділом і має поздовжньоволокнисту структуру.

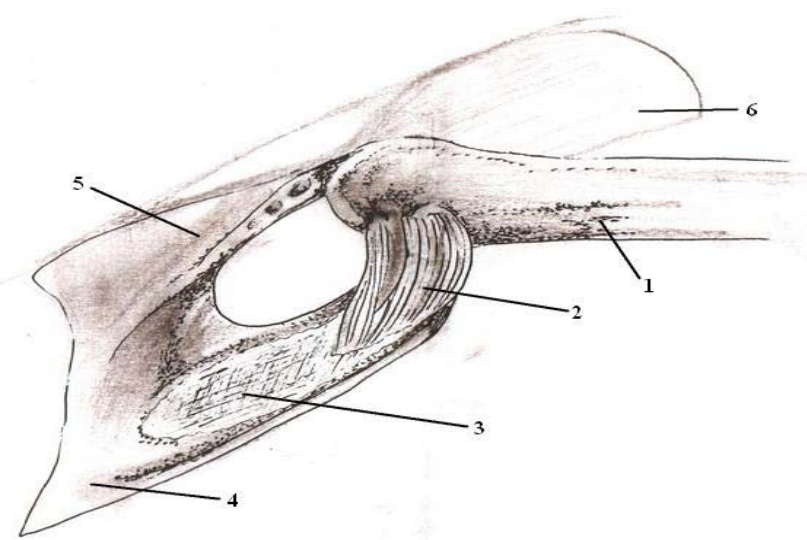

Рис. 6. М'язи тазостегнового суглоба чорного лелеки (латеральна поверхня):

1 - стегнова кістка; 2 -медіальний затульний м'яз; 3 - сухожильна мембрана; 4 - лобкова кістка; 5 - сіднича кістка; 6 - клубова кістка.

Зовнішній клубово-стегновий м'яз у рудої чаплі та чорного лелеки починається тонким апоневрозом від дорсального та дорсо-латерального кінця клубових гребенів. Закінчується потовщеним сухожиллям на латеральній поверхні проксимального кінця стегнової кістки. М'яз має одноперисту структуру.

Каудальний тазово-стегновий м'яз, що також виявлений тільки у чорного лелеки, має одноперисту структуру волокон і починається м'язовоапоневротично від вентрального краю стегнової кістки, а закінчується на межі тазової кістки та хвостового відділу осьового скелета.
Варто зазначити, що у рудої чаплі нами виявлено глибокий сідничо-стегновий м'яз, розміщений між лобково-сідничо-стегновим та внутрішнім тазово-великогомілковим м'язами біля латерального та медіального згиначів гомілки. Починається він широким м'язово-сухожильним початком від дистального краю сідничої кістки й закінчується м'язово у дистальній частині стегнової кістки. М'яз - одноперистий.

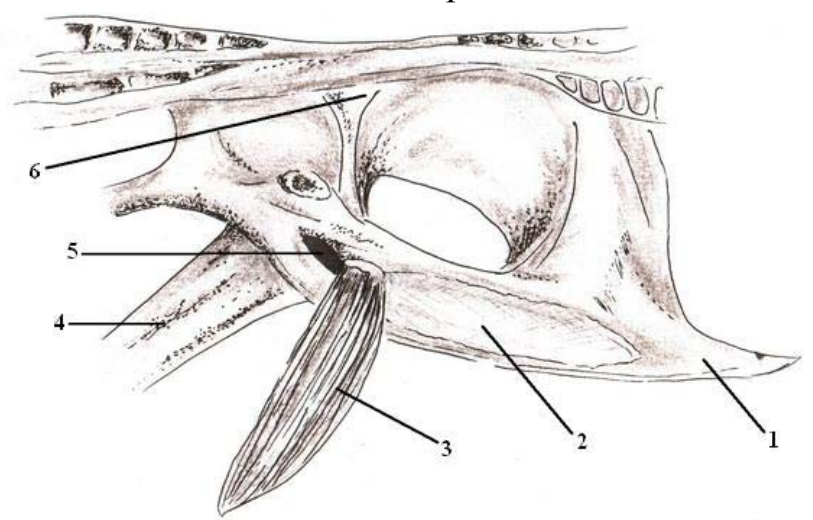

Рис. 7. М'язи тазостегнового суглоба чорного лелеки (медіальна поверхня):

1 - лобкова кістка; 2 - сухожильна мембрана; 3 - медіальний затульний м'яз; 4 - стегнова кістка; 5 - затульний отвір; 6 - тазовий пояс.

Отже, у досліджених лелекоподібних у диференціації м'язів тазостегнового суглоба спостерігаються як подібні, так і відмінні риси, що обумовлено способом пересування та біоморфологічними особливостями статики. Крім того певні відмінності спостерігаються й у ступені розвитку м'язів (див. табл.).

Співвідночення м'язів тазостегнового суглоба лелекоподібних, \%

\begin{tabular}{|c|c|c|c|c|c|c|}
\hline \multirow{2}{*}{ М'язи } & \multicolumn{6}{|c|}{ Вид тварин } \\
\cline { 2 - 7 } & \multicolumn{2}{|c|}{ руда чапля } & \multicolumn{2}{c|}{ чорний лелека } & \multicolumn{2}{c|}{ бугай великий } \\
\cline { 2 - 7 } & маса, г & $\%$ & маса, г & $\%$ & маса, г & $\%$ \\
\hline $\begin{array}{c}\text { Краніальний } \\
\text { клубово-вертлужний }\end{array}$ & 1,7 & 26,5 & 9,9 & 58,5 & 0,5 & 16,6 \\
\hline $\begin{array}{c}\text { Каудальний } \\
\text { клубово-вертлужний }\end{array}$ & 0,9 & 14,0 & - & - & 1,2 & 40,0 \\
\hline $\begin{array}{c}\text { Внутрішній } \\
\text { клубово-стегновий }\end{array}$ & - & - & 0,4 & 2,3 & - & - \\
\hline Медіальний затульний & 0,8 & 12,5 & 2,4 & 14,2 & 0,6 & 20,0 \\
\hline $\begin{array}{c}\text { Сідничо-стегновий } \\
\text { Каудальний } \\
\text { тазово-стегновий }\end{array}$ & 0,8 & 12,5 & 3,5 & 20,7 & 0,7 & 23,3 \\
\hline $\begin{array}{c}\text { Зовнішній } \\
\text { клубово-стегновий }\end{array}$ & 0,2 & 3,1 & 0,1 & 0,5 & - & - \\
\hline $\begin{array}{c}\text { Глибокий } \\
\text { сідничо-стегновий }\end{array}$ & 2,0 & 31,2 & - & - & - & - \\
\hline
\end{tabular}


Аналіз таблиці свідчить, що найбільш потужними серед м'язів тазостегнового суглоба лелекоподібних $є$ краніальний клубово-вертлужний, каудальний клубово-вертлужний, медіальний затульний, сідничо-стегновий та глибокий сідничо-стегновий м'язи. Найменший розвиток се- ред м'язів тазостегнового суглоба притаманний внутрішньому клубово-стегновому, зовнішньому клубово-стегновому та каудальному тазовостегновому м'язам.

Відмінним є і ступінь розвитку м'язових груп тазостегнового суглоба (рис. 8).

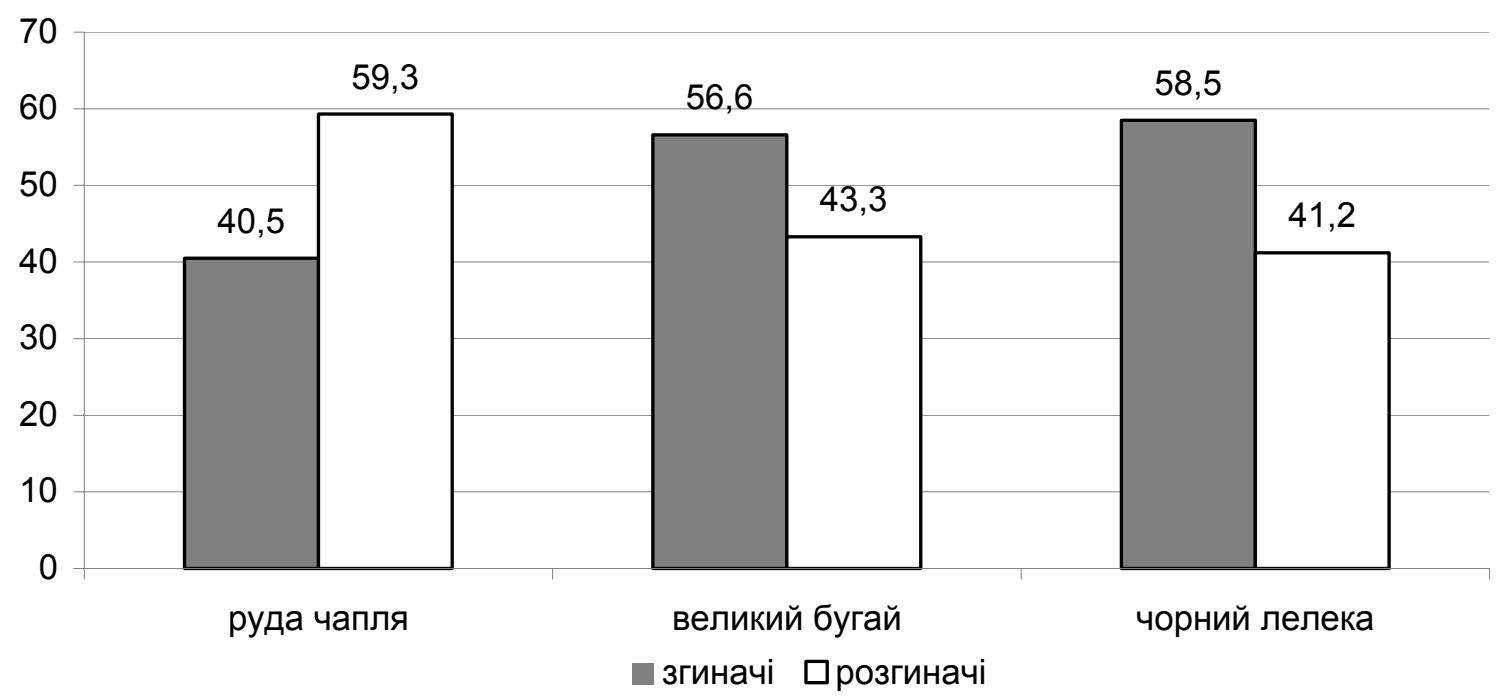

\section{Рис. 8. Співвідношення маси груп м'язів-розгиначів та згиначів до загальної маси м'язів тазостегнового суглоба}

Аналіз графіка показує, що маса м'язіврозгиначів тазостегнового суглоба у рудої чаплі більша від маси м'язів згиначів, а у бугая великого та лелеки чорного навпаки.

Отже, розгинання тазостегнового суглоба у рудої чаплі потребує значно більших зусиль, аніж згинання. У бугая великого та чорного лелеки більше зусиль припадає на згинання суглоба.

Це, у свою чергу, забезпечує утримання тазостегнового суглоба в гравітаційному полі Землі у певному положенні під час статики та локомоції.

\section{БІБЛІОГРАФІЯ}

1. Линдеман $K . E$. Основы сравнительной анатомии позвоночных животных / К. Е. Линдеман. С.-Пб. : Изд-во А. Ф. Маркса, 1899. - 686 с.

2. Мельник О. П. Біоморфологія плечового поясу хребетних: дис. на здобуття вченого ступеня д-ра. вет. наук : спец. 16.00.02 - Патологія, онкологія і морфологія тварин / О. П. Мельник. - К., 2011. $-382 \mathrm{c}$.

3. Мороз $B . \Phi$. Механізми функціонування м'язово-скелетної системи та закономірності іiі розвитку у хребетних : дис. д-ра вет. наук : 16.00.02 / В. Ф. Мороз. - 2003. - 350 c.

4. Homberger D. G. Avian origin revisited/ D. G. Homberger // J. Bioscience, 2003. - Vol. 28. -
Висновки: 1. У представників ряду лелекоподібних ступінь диференціації м'язів тазостегнового суглоба обумовлений крокуючим типом біпедальної локомоції, а також біоморфологічними особливостями статики.

2. Маса м'язів-розгиначів тазостегнового суглоба у рудої чаплі, великого бугая й чорного лелеки більша, ніж маса м'язів згиначів.

3. Розгинання тазостегнового суглоба у рудої чаплі потребує значно більших зусиль, аніж згинання. У бугая великого та чорного лелеки більші зусилля витрачаються на згинання суглоба.

\section{P. 135-141.}

5. Meyer C. E. H. Archaeopteryx lithographica (Vogel-Feder) und Pterodactylus von Solnhofen (in German) / C. E. H. Meyer. - Neues Jahrbuch für Mineralogie, Geologie und Paläontologie, 1861. P. 678-679.

6. Sereno $P$. Early evolution of avian flight and perching: new evidence from the Lower Cretaceous of China / P. Sereno, Ch. Rao // Science, 1992. Vol. 255. - P. 845-848.

7. Zhou Zh. A long-tailed, seed-eating bird from the Early Cretaceous of China / Zh. Zhou, F. Zhang // Nature, 2002. - Vol. 418. - P. 405-409. 